\title{
The Bullshit Doctrine: Fabrications, Lies, and Nonsense in the Age of Trump
}

\author{
LARS J. KRISTIANSEN \\ School of Communication Studies \\ James Madison University \\ 54 Bluestone Drive, MSC 2106 \\ Harrisonburg, VA 22807 \\ United States \\ kristilj@jmu.edu
}

\author{
BERND KAUSSLER \\ Department of Political Science \\ James Madison University \\ 91 E Grace Street, MSC 7705 \\ Harrisonburg, VA 22807 \\ United States \\ kausslbx@jmu.edu
}

\begin{abstract}
Guided by the concept of bullshit, broadly defined as a deceptive form of rhetoric intended to distract and/or persuade, we examine how fabrications and false statements - when crafted and distributed by the president of the United States-impact not only foreign policy making and implementation but also erode democratic norms. Unconstrained by reality, and seemingly driven more by celebrity and showmanship than a genuine desire to govern, we argue that President Trump's penchant for bullshit is part of a concerted strategy to sideline critics while simultaneously undermining the ongoing investigations into the Trump campaign's alleged collusion with the Russian government.
\end{abstract}

Résumé: Guidés par le concept de conneries, largement défini comme une forme trompeuse de rhétorique destinée à distraire et / ou à persuader, nous examinons comment les fabrications et les fausses déclarationslorsqu'elles sont forgées et distribuées par le président des États-Unisinfluencent non seulement la politique étrangère et sa mise en œuvre mais aussi rongent les normes démocratiques. Puisque le président Trump n'est pas contraint par la réalité et est apparemment plus motivé par la célébrité et la mise en scène que par un réel désir de gouverner, nous sommes convaincus que son penchant pour les conneries fait partie d'une stratégie concertée pour marginaliser les critiques tout en minant les enquêtes en cours sur la prétendue collusion de la campagne de Donald Trump avec la Gouvernement russe.

Keywords: bullshit, Donald Trump, foreign policy, post-truth, presidential rhetoric 


\section{Introduction}

On June $16^{\text {th }}, 2015$, Donald J. Trump announced his bid for the U.S. presidency. Having teased a presidential run for nearly three decades, boasting to Oprah Winfrey already in 1988 that "I would never want to rule it out totally... and if I did decide to [run for president]... I would say that I would have a hell of a chance of winning" (OWN 2015), Trump put speculations about his political aspirations to rest as he announced his intention to seek the Republican presidential nomination during a press conference hosted in the lobby of Trump Tower. A political neophyte without previous governmental experience, Trump favored showmanship over substance and tenuously enlisted his wealth, in addition to an insipid display of exaggerated patriotism, as visual stand-ins for aptitude. Stepping up to the microphone, positioning himself between an assemblage of neatly arranged American flags and a podium embellished with his name and campaign slogan, the former Apprentice host delivered an off-the-cuff address covering topics as diverse as the economy, international trade, tax reform, health care, immigration, and terrorism. Roughly fifteen minutes after making his opening remarks, awkwardly pausing for dramatic effect, Trump declared: "Ladies and gentlemen, I am officially running for president of the United States and we are going to make our country great again" (C-SPAN 2015).

Reactions to Trump's campaign announcement were mixed. Conservative commentators were generally favorable in their assessments of Trump's candidacy while their liberal counterparts expressed misgivings about Trump's qualifications and temperament, avidly decrying his lack of both. FOX News (2015), although painting Trump as an "undeniable element of surprise" (para. 6), describing his demeanor as "brash" (para. 19), nonetheless lauded his business acumen and offered that "he could be an aggressive - and interesting - player on the primary debate stage" (para. 8), even if running an "against-the-odds campaign" (para. 1). Applauding Trump's outspokenness, Sean Hannity argued that "I am glad Donald Trump is in this race. I like his outsider's view of politics... I like anybody who is not politically correct" (Adams 
2015, para. 18). $M S N B C$ 's Rachel Maddow, in contrast, questioned the legitimacy of Trump's announcement by interrogating whether his presidential bid was anything more than a PR stunt (Arana 2015). The Huffington Post, a leftist news blog, followed suit by likening Trump's speech to a "rambling" piece of "performance art" (Bobic 2015, para. 1). More damning, perhaps, were reports from non-partisan groups such as The Annenberg Public Policy Center who accused Trump of playing fast and loose with facts (Jackson 2015). Yet, because Trump was deemed a spectacle bereft of substance, concern swiftly gave way to ridicule and The Huffington Post declared, on July $17^{\text {th }}$, 2015, that:

we have decided we won't report on Trump's campaign as part of The Huffington Post's political coverage. Instead, we will cover his campaign as part of our Entertainment section. Our reason is simple: Trump's campaign is a sideshow. We won't take the bait. If you are interested in what The Donald has to say, you'll find it next to our stories on the Kardashians and The Bachelorette. (Grim \& Shea 2015, para. 1)

While the novelty of Trump's campaign announcement generated headlines, his callous and confrontational approach to public address commanded the greater number of column inches. An armchair critic with a profound disregard for political decorum and a diminutive concern for careful deliberation, Trump's rhetorical style mirrored that of a populist demagogue rather than a serious presidential candidate. Under the guise of eschewing political correctness, of merely "telling it like it is", Trump hurled insults not only at the Obama administration but also his fellow Republicans while simultaneously bolstering his business endeavors and deal-making skills. More sinister, however, was Trump's reliance upon divisive rhetoric and racist tropes as he maliciously lambasted Mexican immigrants by shrewdly preying on the fears of the far-right: "When Mexico sends its people, they're not sending their best... They're sending people that have lots of problems, and they're bringing those problems with us [sic]. They're bringing drugs. They're bringing crime. They're rapists. And some, I assume, are good people" (C-SPAN 2015). Peddling sentiments 
that effectively would have rendered traditional candidates unelectable, Trump's uncouth address set the tone for a ramshackle presidential campaign that ultimately landed him the presidency.

Following his campaign announcement, and his subsequent ascent to the office itself, Trump has been described as a bully (Shafer 2017), a clown (Taibbi 2015), a temperamental child (Brooks 2017), a know-nothing (Bernstein 2017), and a national embarrassment (Cox 2015). James even claims that Trump is an asshole (2016). While the goal of this essay is not to assess the accuracy of these depictions, collectively they point to an undeniable conclusion: Donald Trump is a controversial figure. Though the above portrayals might all enjoy some level of accuracy, we suggest that a more productive description is that of Trump as a "bullshitter" or "bullshit artist". Below we demonstrate how Trump's rhetorical style, while interspersed with other deceptive tactics, is fundamentally rooted in what Frankfurt (2005) and others term 'bullshit'. More precisely, we examine how "bullshit" - when crafted and circulated by the president of the United States - influences international relations and foreign policy making. In order to productively examine Donald Trump's rhetoric, it is first necessary to understand the historical context that gave rise to Trump and into which his rhetorical utterances were inserted.

\section{2. "Post-truth" and "alternative facts"}

In 2016, The Oxford English Dictionary's word of the year was 'post-truth' (Wang 2016). Denoting "circumstances in which objective facts are less influential in shaping political debate or public opinion than appeals to emotion and personal belief" (Oxford English Dictionary 2017), thereby sharing striking similarities with Stephen Colbert's neologism 'truthiness', defined as "the quality of seeming or being felt to be true, even if not necessarily true" (Oxford English Dictionary 2017), 'post-truth' has cemented its place in the popular vernacular. Expanding the term's definitional parameters by giving it an eerily Orwellian twist, Kellyanne Conway seamlessly coupled "post-truth" and Trumpism during an interview with $N B C$ 's Chuck Todd. Defending former press secre- 
tary Sean Spicer's claim that Trump's inauguration proceedings gathered "the largest audience to ever witness an inauguration, period" (Stelter 2017, para. 3), Conway argued that Spicer-and the Trump administration by extension - only sought to correct misleading media narratives by supplying their own set of "alternative facts". While arguments about the size of Trump's inaugural crowd ultimately are of limited import, Conway's and Spicer's vacillation toward blatant fabrication is not. Their wanton disregard for factual reporting, as well as their proclivity for publicizing easily discreditable nonsense, not only undermines the credibility of the executive branch but also provides worrying insight into the president's character and motives. Appearances, one might conclude, matter a great deal more to President Trump than does accuracy. In discussing the relationship between "post-truth" reasoning and politics, and in so doing capturing the ethos of the Trump administration rather poignantly, Will Fish explains that "post-truth" rhetors generally display

a willingness to issue warnings regardless of whether there is any real sense of events being likely to come about, or make promises that there is no real commitment to keeping, or make claims there is no real reason to believe are true, all for the purpose of gaining electoral advantage. (2016, p. 211)

Granted, truth is a complicated concept. Historically derived, contextually informed, subjectively determined, and ultimately distorted by innate inadequacies in the human sensory apparatus, the establishing of truth-or falsity for that matter-is a difficult proposition (Kuhn 1962). In the realm of human activity, where strict syllogistic reasoning is the exception rather than the rule, formal logic has been eclipsed by more pragmatic and contextually anchored reasoning frameworks. Following the postmodern turn, which brought to light the cultural, historical, and political situatedness of not only human subjectivity but of knowledge production itself, formal logic has been recast as an unattainable ideal rather than a dependable implement for argument (Ward 1996). While this does not mean that any conclusion can be drawn from any type of evidence, "post-truth" rhetors nonetheless seek to 
exploit this insight by claiming that veracity is fundamentally a subjective endeavor. Yet, as Frankfurt offers, "[t]here is a dimension of reality into which even the boldest-or the laziestindulgence of subjectivity cannot dare to intrude" (2006, p. 26).

In the political arena, where truth routinely is determined by majority rule and consensus frequently trumps facticity, "posttruth" appeals and arguments produce noteworthy problems. A functioning democracy, after all, requires that voters are granted unhindered access to accurate, reliable, and truthful information. "Post-truth" rhetors, however, do not view the sanctity of the democratic enterprise as a top priority. Their goal is winning elections by securing competitive advantage and any tactic that might help ensure victory is deemed fair game. In the current political climate, heavily populated with polarizing claims crafted by ideologues masquerading as journalists, the propagation and dissemination of "post-truth" statements have been exceptionally successful in disrupting audiences' rational decision-making processes. Veracity, one might speculate, is currently being sacrificed at the altar of ideology (Roberts 2017). Not only is the president taking part, he is leading the charge by waging war on the nation's media institutions (Gold 2017). With frequent admonitions that even respectable news organizations like $C N N$ and the New York Times are peddling "fake news", President Trump is hard at work trying to ensure that unquestioned assumptions and personal opinions are elevated to the level of proof by undermining the very concept of objective knowledge.

\section{3. "Bullshitter-in-chief"}

Originally published in Raritan in 1986, Harry Frankfurt's philosophical treatise On Bullshit is the first sustained academic treatment of the subject. Taking as his point of departure the assertion that "[o]ne of the most salient features of our culture is that there is so much bullshit", offering that "[e]veryone knows this" and that "[e]ach of us contributes his share" (2005, p. 1), Frankfurt endeavors to not only theorize the conceptual dimensions of bullshit by probingly defining the term but also seeks to distinguish bullshit 
from other forms of dishonesty - lying in particular - by examining bullshit's relationship with truth. Rampant in advertising (Kotzee 2007), endemic in politics (Belfiore 2009), widespread in academic writing (Cohen 2002), and pervasive in interpersonal relationships (Olsson 2008), bullshit transcends context and supplants circumstance. Bullshit, Frankfurt contends, is everywhere. Even so, and quite in spite of its cultural ubiquity, bullshit has remained largely undefined because it is "often employed quite loosely - simply as a generic term of abuse, with no very specific literal meaning" (Frankfurt 2005, p. 2). While Frankfurt's original treatise received only marginal attention, the Princeton University Press' republication of his essay as a book in 2005 sparked newfound interest in the concept. A small but productive canon of work, which we examine below, has since developed in efforts to clarify and crystallize the concept.

In Frankfurt's original essay, bullshit is presented as a deceptive form of rhetoric whose ultimate goal is distraction or persuasion through attempts to "manipulate the opinions and the attitudes of those" (Frankfurt 2006, p. 4) with whom the bullshitter communicates. Although sharing conceptual similarities with lying, bullshit is nonetheless different from lying because it is, in Frankfurt's view, wholly unconcerned with truth. Whereas the liar deliberately makes statements designed to mislead by directing attention away from what the liar believes to be true, thus betraying at least a provisional concern for truth-value on the part of the liar, the bullshitter holds no special regard for accuracy and is quite unperturbed by the prospect of misrepresenting reality. For the bullshitter, the relative truthfulness or falsity of a particular claim is not only secondary but irrelevant. Therefore, and quite unlike the liar, who assumes to know what is true but nonetheless tenders falsity, the bullshitter "cannot be regarded as lying; for she does not presume that she knows the truth, and therefore she cannot be deliberately promulgating a proposition that she presumes to be false" (Frankfurt 2005, p. 33). In order to invent effective lies and convincingly pass falsehood off as fact, an activity that demands at least provisional "respect for the institution of truthtelling, albeit a parasitic one" (Aberdein 2006, p. 152), the liar 
needs to know not only what is true but must also have a working understanding of the context into which the false claims are inserted. The bullshitter suffers no such burden. Unrestrained by the pressures of reality, the bullshitter is even "prepared, so far as required, to fake the context as well" (Frankfurt 2005, p. 52). It is this lack of concern for truth, "this indifference to how things really are" (p. 34), that Frankfurt regards as the central feature of bullshit.

Of course, just because something might rightfully be described as bullshit does not invariably mean that it also is false, for it is entirely possible to accidentally speak truth. As such, the term bullshit, at least in Frankfurt's estimation, is better defined by its communicative intent than the contents of its expression. What this means is that the essence of bullshit is not simply "that it is false[,] but that it is phony" (Frankfurt 2005, p. 47). As Kotzee explains, it is "not the truth or falsity (or even meaninglessness) of a sentence that makes it bullshit; it is that it is uttered without concern for what is true" $(2007$, p. 168). What the bullshitter seeks to misrepresent, therefore, is neither reality itself nor the things in it, but rather his/her intentions. According to Frankfurt, the "bullshitter may not deceive us, or even intend to do so, either about the facts or about what he takes the facts to be. What he does necessarily attempt to deceive us about is his enterprise" (2005, p. 54). For this reason, the bullshitter's "only indispensably distinctive characteristic is that... he misrepresents what he is up to" $(2005, \mathrm{p}$. 54). Ultimately, the bullshitter

is neither on the side of the true nor the side of the false. His eye is not on the facts at all, as the eyes of the honest man and the liar are, except insofar as they may be pertinent to his interest in getting away with what he says. He does not care whether the things he says describe reality correctly. He just picks them out, or makes them up, to suit his purposes. (Frankfurt 2005, p. 56)

Nonetheless, if the bullshitter hopes to be effective in realizing his/her goals, whatever those goals may be in the given case, it is crucial - for matters of retaining credibility and generating sufficient persuasive force, either through assertion or by implicature- 
that the bullshitter is also is careful to "conceal the lack of concern for truth" (Webber 2013, p. 657). If not, the bullshitter might soon be pegged a liar, an accusation that is far more damaging to the speaker's credibility than are accusations that the speaker deals in bullshit (Frankfurt 2005).

Although Frankfurt concedes that his original project is one of giving "a rough account of what bullshit is and how it differs from what it is not-or (putting it somewhat differently) to articulate, more or less sketchily, the structure of its concept" (p. 2), his work is not without its critics. Taking issue with Frankfurt's modernist assumptions (Reisch 2006; Smagorisnky et al. 2010), his narrow focus on semantics and truth-value (Olsson 2008; Zavattaro 2017), as well as his treatment of bullshit as a seemingly monolithic concept (Carson 2016; Cohen 2002), scholars have sought to rework and amend his initial theorizations.

The first attempt to do so is offered by Cohen (2002). Arguing that there are important conceptual differences between intentional and unintentional bullshit, as well as between bullshitting (an intransitive verb describing an activity) and bullshit (a noun describing a thing), Cohen maintains that bullshit as process should not be confused with bullshit as product, stating that bullshit (the product) can be generated without also engaging in bullshitting (the process). In clarifying this difference, Kotzee (2007) offers that "not all bullshit is bullshit because it was produced with a bullshitting intention: some of it is bullshit simply by virtue of the features of the utterance itself, independently of the speaker's intention" (p. 169). This type of bullshit, Cohen explains, is endemic in academia and is usually expressed in the form of "unclarifiable unclarity" (2002, p. 333). Conceptually inspired by adoxography, describing "the inflated vocabulary and obfuscating syntax employed to veil a poverty of substance in academic essays" (Smagorinsky et al. 2010, p. 372), "unclarifiable unclarity" defines language that is so complex, jargonized, imprecise, or confusing that it is functionally impossible for message recipients to draw meaningful conclusions or even judge the logical merits of the arguments presented. What Cohen is critiquing, then, is Frankfurt's insistence that bullshit is inherently deceptive and that it 
needs to be intentional, claiming instead that it is possible for honest and ethical people to accidentally produce bullshit without engaging in the bullshitting process so central to Frankfurt's argument (Carson 2016; Kotzee 2007).

Complicating the relationship between bullshit and truth by offering a pluralist perspective, arguing that truth is not fundamentally an objectively verifiable concept and that legitimate discussions might be had about what is true "about the world, how it works, [and] about our place in it", Reisch (2006, p. 37) further distinguishes between semantic bullshit and pragmatic bullshit. While semantic bullshit is similar to the bullshit discussed by Frankfurt (and to some extent Cohen), taking as its subject the circulation of statements in which the bullshitter shows no appreciable regard for truthfulness or falsity, pragmatic bullshit asks us to consider "the uses and purposes to which language may be put" (Reisch 2006, p. 41) and "addresses the goals of the bullshitter in terms of trying to achieve something potentially legitimate while fudging the truth" (Smagorinsky et al. 2010, p. 371). More precisely, pragmatic bullshit springs from a concrete "aim to coordinate two (or more) distinct concerns or conversations and to use one as a cover or container for the other" (Reisch 2006, p. 42). Kellyanne Conway's defense of Sean Spicer, in which she invokes the term 'alternative facts' to defend and bolster the Trump administration's credibility, is an apt example of pragmatic bullshit in the Reischian sense.

While it is true that 'alternative facts' is a term used in the legal profession, Conway is attempting to use legal jargon-which in a news context should appropriately be labelled bullshit - to deflect accusations that Spicer was lying about the size of President Trump's inauguration audience. Conway's hope is that by using a legal term - even if contextually inappropriate - she might imbue the semantic container 'alternative facts' with undue credibility and persuasive force. Although ethically questionable, this is a clever strategic move because bullshit is generally treated more benignly by audiences than is outright lying (e.g., Belfiore 2009; Webber 2013). Of course, because the size of Trump's inauguration audience is not a legal question, for the president is not for- 
mally on trial even though he is subject to scrutiny in the court of public opinion, the invocation of legal terminology-which is appropriate in a very different context - is a bullshit attempt on Conway's part to derail mounting criticism by having claims in one conversation stand in as evidence in another. In short, language that is appropriate in one highly particular context (legal proceedings) is enlisted as argumentative clout in a new and novel context (inauguration audience size) in which the term loses its intended meaning. Conway herself seems indifferent as to whether this conceptual transfer produces a claim that is true or false. She only cares about the outcome, namely that people accept the assertion itself.

President Trump's comments about the size of his inauguration audience, on the other hand, better fits Frankfurt's (2005) definition of bullshit. While Trump is not at all indifferent about the size of his inauguration crowd, he appears quite indifferent as to whether his responses to news reports discussing the crowd size are true or false. That is, Trump is indifferent about the relative truthfulness of his own claims while simultaneously caring deeply about the reception of those claims. The president, in other words, seems concerned about popular perception and the symbolic significance of the audience size more so than whether his crowd was, in actual fact, larger than those of his predecessors. One might even posit that Trump would not really care to find out what the numbers actually were as long as he gets to stake his false claim, that he ultimately cares more about perception than he does reality, and further speculate that - for President Trumpperception equals reality. If something is thought to be true in the minds of audiences, then for them that belief might as well be true. For this reason, and paraphrasing Frankfurt, Trump is deceiving us not necessarily about reality itself or the things in it, he is deceiving us about what he is up to. After all, the size of his inauguration audience only matters insofar as it is an implicit measure of the president's popularity and perceived electoral support. His arguments on this point, therefore, must be considered bullshit because they merely serve as proxies for an unstated primary goal. 


\section{Kristiansen and Kaussler}

Pragmatic bullshit, ultimately, is geared towards the realization of goals and puts a premium on the production of tangible effects rather than the establishing of truth (Frankfurt) or the creation of shared meaning (Cohen). As such, bullshit might even be construed - given the right circumstances - as something productive. This argument is pursued by Zavattaro (2017) who argues that bullshit, once removed from the realm of philosophy, logic, and rhetoric, and examined from a sociological rather than epistemic vantage, is not only a powerful social device but also a defensible practice. A pragmatic conception of bullshit also allows us to consider the possibility that not everything a bullshitter says should be counted as bullshit because bullshit can easily be embedded in a complex web of reasonable assertions and plausible implicatures as speakers move fluidly from topic to topic and, possibly, from fact to fiction. After all, it is entirely possible to pursue legitimate social goals through bullshit while simultaneously speaking authoritatively about a topic of concern before transitioning back to bullshit because the speaker has been tasked with discussing a topic about which s/he enjoys limited expertise or experience. In the end, and quite in spite of additional theorization and reconceptualizations, no agreed-upon definition of bullshit exists in the literature. As Reisch explains, "Frankfurt admits that his definition of bullshit leaves us with a puzzle... some twenty years later, the puzzle remains unsolved" (2006, p. 33). Carson speculates that the reason for this is that "the concept of bullshit is too loose and amorphous to admit of a definition in terms of necessary and sufficient conditions" (2016, p. 66).

Despite diverging accounts regarding definitional matters, widespread agreement exists vis-à-vis the relative offensiveness of bullshit. While Frankfurt holds that bullshit is a greater enemy of truth than is lying, a point widely contested by others (e.g., Sakama et al. 2014; Webber 2013), he also explains that "people tend to be more tolerant of bullshit than of lies, perhaps because we are less inclined to take the former as a personal affront" (2005, p. 50). The conception that bullshit is less insidious than lying is also shared by Belfiore, who offers that "society seems to be prepared to treat the bullshitter with more leniency than it does 
the liar" (2009, p. 344), and Webber who argues that lying "damages both credibility in assertion and credibility in implicature," whereas misleading (of which bullshit is part) "damages only credibility in implicature" (2013, p. 651). Sakama et al., in subjecting various forms of dishonesty to the rules of multi-modal logic, and as such laying out their conceptual properties by employing an analytical "framework based on formal logic" (2014, p. 290), arrange common deceptive tactics on a credibility continuum ranging from "untrusted" to "trusted" (p. 283). At the far end, and thus most detrimental to a speaker's credibility, is lying. Following lying, and presented in a descending order of detriment, is bullshitting, withholding of information, and the telling of half-truths ( $\mathrm{p}$. 283). Reaching the same conclusion, and echoing Frankfurt's advice to "never lie when you can bullshit your way through" (Frankfurt 2005, p. 48), Webber offers that "we have good reason to respond with greater opprobrium to lies than to bullshit" (2013, p. 658). Even so, honesty is generally "the best policy. But if you must depart from it, then you should mislead first, bullshit second and lie only as a last resort" (Webber 2013, p. 659).

Although the accounts reviewed above all provide valuable insights, few of them offer actual examples of real-world bullshit. In the available literature, bullshit is generally treated as a thought exercise and most of the existing accounts are rooted in hypothetical, historical, and/or literary examples. Aside from Smagorinsky et al.'s study of bullshit in student writing, Belfiore's study on bullshit in British cultural policy, and a small collection of writings in the book edited by Hardcastle and Reisch (2006), application essays are almost non-existent. This current study seeks to amend this problem. If bullshit is indeed as prevalent and widespread as Frankfurt and his critics suggest, more work should be conducted in order to point out actual uses and abuses of bullshit. Given the power afforded to U.S. presidents by virtue of the office they occupy, presidential bullshit seems an apt point of departure.

So, what then, is bullshit? Rather than seeking to clarify unclarities, to arrive at statements that might be deemed true, even if only provisionally, bullshit seeks to obscure, mislead, and obfuscate - to render difficult to determine those things that might 
actually be rather straightforward. It is generally accompanied by a bullshitting intention, but can also be produced inadvertently. Moreover, bullshit is both a product and a process and is commonly called into existence when people are asked to speak on matters about which they have little or no expertise or experience (Frankfurt 2005). Enlisted in support of unstated primary goals, bullshit can also be evasive when used strategically to distract audiences from a speaker's actual motives. As such, and as regards the rhetorical style of President Trump, we are not suggesting that everything the president says should be counted as bullshit, for he also lies, tells the truth, and frames situations to suit his purposes. We are, however, suggesting that his penchant for bullshit muddies the proverbial waters to the point where it is often difficult to determine what is true and what is not. In short, Trump frequently peddles bullshit in the Frankfurtian, Cohenian, as well as Reischian senses of the term.

\section{The emerging bullshit doctrine}

As of November 14, 2017, President Trump had publicly made 1,628 false or misleading claims, an average of 5.5 per day during his presidency (Kessler, Kelly and Lewis 2017). False and misleading claims promulgated by the president usually include praise for himself and his policies or they seek to demean or discredit his detractors. Given Trump's history of self-promotion, and his propensity for ridiculing opponents, this is not surprising. Nonetheless, Trump's approach to bullshit sets him apart from the average politician, for he moves so fluidly between fabrication, fantasy, and deception that standard mechanisms for dealing with falsehoods no longer apply. As George Will explains, Trump's rhetorical style is "not merely the result of intellectual sloth but of an untrained mind bereft of information and married to stratospheric self-confidence" (2017, para 1). Surprisingly, rather than suffering lasting negative consequences, Trump often emerges unscathed even after his spurious claims are debunked. He is even wont to double down on discredited nonsense. As such, Trump 
takes us into uncharted bullshit territory, not least because of the power afforded by the office he occupies.

An apt example is Trump's kneejerk reactions to Michael Flynn's confession that he lied to FBI agents about his conversations with Russian Ambassador Sergey Kislyak during the presidential transition period. This episode represents a sequence of apparent lies that concluded with a series of bullshit statements. In a tweet, the president claimed he "had to fire General Flynn because he lied to the Vice President and the FBI" (Carter 2017, para. 5). It is unclear why Trump would tweet such a statement. If true, he might have incriminated himself by admitting to obstruction of justice. In June, 2017, James Comey testified in congress that Trump had asked him to end the investigation of Flynn and that the president had demanded a pledge of loyalty. ${ }^{1}$ When the ranking Democrat on the Senate Judiciary Committee, Senator Feinstein (D-Calif.), stated she believed that an obstruction of justice case against the president was forming as part of the ongoing Senate investigation (Meet the Press with Chuck Todd 2017), Trump tweeted "I never asked Comey to stop investigating Flynn. Just more Fake News covering another Comey lie!" (Trump 2017c). While it is difficult to (dis)prove that the former FBI director lied under oath, it seems unlikely that he would do so. Moreover, Trump stated in an NBC interview in May of 2017 that he fired Comey because of the FBI investigation into Russian election meddling (Holt 2017). Most likely, Trump lied to cover up his reckless and self-incriminating tweet.

Following these attempts at exoneration, Trump crafted a series of bullshit statements aimed at discrediting the entire investigation in which he claimed - contrary to his own FBI directorthat the reputation of the FBI was in "tatters - worst in History!" (Trump 2017d). He also claimed that Hillary Clinton had lied to

\footnotetext{
1 The investigation by Special Prosecutor Robert Mueller is probing potential obstruction of justice by White House staff or the president during the 18-day period after the White House was informed by the Acting Attorney General Sally Yates that Michael Flynn was susceptible to blackmail by the Russian government.
} 
the FBI despite the agency never stating that she made false statements: "Hillary Clinton on 4 July weekend went to the FBI, not under oath - it was the most incredible thing anyone has ever seen - lied many times, nothing happened to her. Flynn lied, and it's like - it ruined his life. It's very unfair" (Smith \& Pengelly 2017, para. 4). A U.S. president openly showing contempt for two federal agencies, the FBI and the Department of Justice, by fabricating falsehoods to protect himself is unprecedented. That lying is a strategy used by politicians is not new, it is a part of statecraft (Kaussler and Hastedt 2017). For populists like Trump lying is an effective tool by which to rally supporters by playing on tribalism, thereby reinforcing biases already shared among members of the electorate. However, unlike shrewd statesmen before him, Trump's impetuous and off-the-cuff fabrications do not fit the established mold. Even Richard Nixon pretended in public to be subject to the rule of law-even though he broke and considered himself above it. Trump's nepotism and admiration for strong man politics is closer to authoritarian structures than it is to a liberal democracy. This aspect of the Trump presidency brings us the closest to Frankfurt's original definition of bullshit. Since Trump does not appear to be guided by the rule of law, but seems instead to have embraced an authoritarian interpretation of "power-based law" over "rule-based law", his bullshit ultimately serves to realize political goals rather than establishing truth. More than just covering up illicit dealings or occasionally lying to grease the wheels of a sluggish political machine, bullshit is the modus operandi of the Trump administration. When promulgated with impunity by a sitting president, such bullshit constitutes a real threat to democratic norms and institutions.

Trump's emerging bullshit doctrine is both personal and political in nature. The first category of bullshit derives not only from the president's abovementioned contempt for the rule of law, but also from a lack of basic competence and interest in the U.S. political system, its governance, and international affairs. Indeed, many of Trump's statements - delivered via Twitter or during speeches and interviews - must be considered bullshit because not only are 
they uninformed and untrue, they merely serve populist purposes. That is, they are aimed at insulting, discrediting, and smearing critics while simultaneously inflating or fabricating the president's accomplishments in order to make him look competent. This type of bullshit is primarily rooted in Cohenian obfuscation, but also has direct pragmatic manifestations in the Reischian sense. In the realm of foreign policy, Trump's bullshit is largely Cohenian and appears the inevitable result of a political novice tasked with speaking on topics about which he enjoys only limited expertise, experience, or interest.

Bullshit falling into the second category brings us closer to Frankfurt and Reisch in that the immediate political goal is to undermine ongoing investigations of the Trump campaign and further to contradict the collective assessment of his own intelligence appointees about the nature and scope of the Russian threat to American democracy. For example, following yet another school shooting, this time in Parkland, FL, the president took to Twitter in an attempt to further his political goals by recasting the tragic event as evidence that the FBI is incompetent, unreliable, and untrustworthy: "Very sad that the FBI missed all of the many signals sent out by the Florida school shooter. This is not acceptable. They are spending too much time trying to prove Russian collusion with the Trump campaign - there is no collusion" (Held 2018, para. 4). In much the same way that Kellyanne Conway used legal terminology to defend Sean Spicer's false claim that Trump's inauguration was the most highly attended inauguration in history, Trump is implying that because the FBI failed to apprehend the shooter prior to committing the crime, they are also incapable of providing credible evidence in other situations. The implied logic, which follows the bullshit pattern outlined by Reisch (2006), stipulates that if the FBI cannot outwit and apprehend a teenager, then how can the bureau possibly offer credible testimony in a much more complicated case? By connecting two stories that are inherently unrelated, and using one as argumentative clout in the other, Trump is seeking to diminish the FBI's credibility by engaging in pragmatic bullshit. If Trump can successfully discredit the FBI, then whatever they might find as part of their investigation 
will ultimately be of limited import. That, at least, seems to be the president's reasoning.

Because Trump's radical populism is tied to white-identity politics, and displays a weakness for authoritarianism, his demagogic rhetoric remains underwritten by apparent absurdity as well as bullshit and often masquerades as either policy proposals or historical references. In a tweet following the terrorist attacks in Barcelona, Trump praised a previously discredited story claiming that General Pershing ordered the execution of Muslim insurgents with bullets soaked in pigs' blood during the U.S. war in the Philippines in the early 1900s. The tweet called for people to "Study what General Pershing of the United States did to terrorists when caught. There was no more Radical Islamic Terror for 35 years!" (Fabian 2017, para. 2). After his ouster, former Trump campaign manager Corey Lewandowski said that his team knew that the story was a myth but let Trump tell it at rallies anyway, telling the Washington Post in 2016 that "[i]t's not about that. Look it's an analogy" (Fabian 2017, para. 5). When the president retweeted inflammatory and unverified anti-Muslim videos from a British right-wing extremist group in November 2017, Prime Minister Theresa May said that Trump was "wrong" to disseminate material from a group that promotes "hateful narratives" (Parker and Wagner 2017, para. 7). However, the White House Press Secretary's (Sarah Huckabee Sanders) defense of Trump's redistribution of unverified Islamophobic videos argued that it did not matter whether the videos were fake or not, emphasizing instead the context of national security threats. Sanders stated: "whether it is a real video, the threat is real and that is what the President is talking about, that is what the President is focused on is dealing with those real threats, and those are real no matter how you look at it" (Channel 4 News 2017). While Trump's bullshit aimed at domestic audiences might be the result of deliberate plans or intellectual sloth, or a combination of the two, his ignorance and lack of interest concerning the intricacies of foreign policy makes his bullshit aimed at foreign audiences almost entirely Cohenian. Not only does Trump forego reading the President's Daily Brief, he is easily manipulated by foreign leaders (letting them explain U.S. posi- 
tions to him), and also fails to fully grasp the nature of collective security (Graham 2017). Unwilling to make the requisite effort, and as such speaking without the necessary evidentiary backing, Trump is habitually poised to bullshit out of sheer necessity.

When confronted about the lies perpetuated by Trump during his time in the White House, Kellyanne Conway told CNN's Brian Stelter that they did not constitute lies because Trump believed them:

Stelter: The scandals are about the President's lies. About voter fraud, about wiretapping, his repeated lies about those issues. That's the scandal.

Conway: [Donald Trump] doesn't think he's lying about those issues, and you know it. (Cillizza 2017, para. 2-3)

The Guardian's Lindy West even argues that Trump has weaponized nonsense, stating that:

Without language, there is no accountability, no standard of truth. If Trump never says anything concrete, he never has to do anything concrete. If Trump never makes a statement of commitment, Trump supporters never have to confront what they really voted for. If his promises are vague to the point of opacity, Trump cannot be criticized for breaking them. (2017, para. 8)

As the White House began defending the president's controversial statements as "jokes" (e.g. when he thanked President Putin on Twitter for expelling U.S. diplomats from the U.S. Embassy in August or his endorsement of police brutality before a crowd of police officers on Long Island in July 2017), West Wing staff effectively enabled the president to bullshit with impunity.

So much as these fabrications may be the result of alleged jokes, intellectual deficiencies, lack of competence, knowledge, or training, Kellyanne Conway's proposed defense that Trump believed in his fabrication seem particularly pronounced in one watershed bullshit statement: the claim that President Obama bugged Trump Tower during the election. This claim became a cornerstone of a subsequent misinformation campaign by the president in an effort to undermine and discredit congressional and 
FBI investigations into alleged collusion. On March $4^{\text {th }}, 2017$, President Trump tweeted "Terrible! Just found out that Obama had my 'wires tapped' in Trump Tower just before the victory. Nothing found. This is McCarthyism!" (Trump 2017a). He continued in another tweet: "How low has President Obama gone to tapp [sic] my phones during the very sacred election process. This is Nixon/Watergate. Bad (or sick) guy!” (Trump 2017b). Trump's accusations lacked any proof and were immediately denied by President Obama's spokesperson, by former FBI Director James Comey, as well as former Director of National Intelligence, James Clapper. Clapper told NBC's Meet the Press with Chuck Todd that there was no "Foreign Intelligence Surveillance Act (FISA) request to wiretap President Donald Trump during the election" (Schmid and Shear 2017, para 20). The next day, Sean Spicer said during the White House press briefing that "neither the White House nor the president will comment any further" and proceeded to put the burden of proof on the congressional intelligence committees to exercise their oversight to determine whether Obama abused executive powers (Politifact 2017, para. 9). The White House spokesperson, Sarah Huckabee Sanders, then falsely claimed that "[e]verybody acts like President Trump is the one that came up with this idea... There are multiple news outlets that have reported former President Barack Obama ordered wiretapping on Trump" (Politifact 2017, para 13).

The White House would continue with damage control as Sean Spicer suggested on March $13^{\text {th }}$ that Trump did not mean that Obama literally wiretapped him: "If you look at the president's tweet, he said very clearly quote-'wiretapping' - end quote", thus suggesting that the president did not necessarily mean there was a physical tap on his phones (Politifact 2017, para. 18). While Trump himself tried to justify his allegations during an interview on Fox News and falsely referenced a January $20^{\text {th }}, 2017$, article from The New York Times in which, according to Trump, they "were talking about wiretapping", the allegation was eventually denied during a House Intelligence Committee meeting. Both James Comey and NSA Director, Mike Rogers, stated that there was no information from intelligence agencies or the Department 
of Justice supporting those tweets (Politifact 2017, para. 21). Trump's fabrication about President Obama having ordered surveillance of Trump Tower phone lines was primarily bullshit but it was still meant to undermine the credibility of the FBI. His subsequent accusations that the investigation was the greatest witch hunt in American history continued this fabrication. When pressed about his accusations against President Obama during a CBS interview in the Oval Office in May 2017, he insisted that he was proven right because everyone was still talking about the matter while recasting his allegations as a matter of his own personal opinion:

Dickerson: Did President Obama give you any advice that was helpful? That you think, wow, he really was-

Trump: - Well, he was very nice to me. But after that, we've had some difficulties. So it doesn't matter. You know, words are less important to me than deeds. And you-you saw what happened with surveillance. And everybody saw what happened with surveillance-

Dickerson: Difficulties how?

Trump: - and I thought that - well, you saw what happened with surveillance. And I think that was inappropriate, but that's the way-

Dickerson: What does that mean, sir?

Trump: You can figure that out yourself.

Dickerson: Well, I - the reason I ask is you said he was- you called him "sick and bad."

Trump: Look, you can figure it out yourself. He was very nice to me with words, but- - and when I was with him — but after that, there has been no relationship.

Dickerson: But you stand by that claim about him?

Trump: I don't stand by anything. I just- you can take it the way you want. I think our side's been proven very strongly. And everybody's talking about it. And frankly it should be discussed. I think that is a very big surveillance of our citizens. I think it's a very big topic. And it's a topic that should be number one. And we should find out what the hell is going on. 
Dickerson: I just wanted to find out, though. You're-you're the president of the United States. You said he was "sick and bad" because he had tapped you-I'm just-

Trump: You can take - any way. You can take it any way you want.

Dickerson: But I'm asking you. Because you don't want it to beTrump: You don't-

Dickerson: - fake news. I want to hear it from-

Trump: You don't have to-

Dickerson: - President Trump.

Trump: - ask me. You don't have to ask me.

Dickerson: Why not?

Trump: Because I have my own opinions. You can have your own opinions.

Dickerson: But I want to know your opinions. You're the president of the United States.

Trump: Okay, it's enough. Thank you. Thank you very much.

(Dickerson 2017, para. 66-87)

After the non-partisan group American Oversight filed a Freedom of Information Request to the FBI and the DoJ to obtain documents related to the purported wiretapping, both agencies wrote in a summary judgment court filing on September 1, 2017, that "they do not have any such records by consulting with personnel knowledgeable about Director Comey's statements and the surveillance activities of the FBI" (Abramson 2017, para. 2). The charges against former campaign manager, Paul Manafort, brought by the Special Counsel also did not support Trump's allegations against Obama. There is no evidence that President Obama committed a crime by ordering surveillance of the Trump campaign in 2016 and the legal surveillance of Manafort by the FBI occurred after the campaign and was solely targeted at Manafort.

Domestically, this episode-when coupled with Trump's history of frivolously attacking federal agencies, U.S. media institutions, members of the opposition, and even ordinary members of the public-represents a fundamental erosion of democratic norms in a liberal democracy. A democratic polity, after all, requires truth to function. When power and truth 
become completely unhinged at the highest level, democratic norms are deliberately being undermined. One year into his presidency, Trump has no stable grammar for truth. Indeed, after entering the political arena as a self-avowed Washington "outsider", he has instead displayed contempt for the rule of law and democratic governance and it appears that the president perceives himself as subject to a different set of rules or perhaps no rules at all. Being called on his bullshit seems to have limited impact as fact-finding ventures by the press are routinely discarded as "fake news".

While populism mixed with bullshit may have a long-term impact on democratic norms, nonsense in diplomacy bears more immediately tangible effects. Domestically, loyalists on either side of the political spectrum may be willing to suspend critical reflection on truth. The international arena, however, is less forgiving. Here bullshit is more likely to attract rejection and hostile reactions by allies and antagonists alike.

The Trump administration's foreign policy during its first eight months in office was marked as much by severe infighting inside the White House, and across the entire executive branch, as it was by a struggle over ideology, substance, and direction. After eight months, key members of the administration, including the Chief of Staff, Reince Priebus, National Security Adviser, Michael Flynn, Press Secretary, Sean Spicer, and Chief Strategist, Steve Bannon, either resigned or were sacked. Generally, as far as diplomacy is concerned, the first year represents a learning curve for any new president, particularly foreign policy neophytes like George W. Bush, Bill Clinton, and Barack Obama. While Trump is unique in that he lacks previous governmental experience, he has also shown little interest in acquiring substantive input in order to make up the difference. From the outset, he resisted national security briefs during the transition and often talked about what he learned from foreign heads of state (e.g., from China about North Korea). An ardent viewer of Fox \& Friends, Trump used the show's opinions and often inaccurate accounts for his own political arguments or tweets (Mackey 2017). He shared code-word level intelligence with the Russian foreign minister and ambassa- 
dor during their visit to the White House and confirmed a covert CIA program to arm and train Syrian rebels to remove Bashar alAssad from power in a tweet (Ward 2017). Ultimately, foreign policy during this period was informed by the president's recklessness, impulsiveness, and ignorance, but particularly by bullshit. While tensions between first-time National Security Council staff and other political appointees in the West Wing and permanent bureaucrats across federal agencies are common for any administration, foreign policy was often contradicted or undermined by the president himself. In international relations, maintaining the status quo and reducing uncertainty about intentions is one of the most important elements of international stability. As the new administration was withdrawing from international agreements like the Paris Accord, leaving NATO members wondering about the U.S.'s commitment to the alliance, the U.S. Ambassador to the UN, Nikki Haley, claimed that it served as negotiation leverage with foreign countries. At the House Foreign Affairs Committee, she reflected:

I deal with 192 [countries], and the overwhelming feeling is that we are unpredictable; they don't know exactly what we are going to do... It has kept them more on alert, of wanting to be there with us, not wanting to get on the wrong side of us. (Lynch, C 2017, para. 3)

Credibility is sacrosanct in international relations and Trump lacks it. Far from creating leverage, the president keeps undermining the efforts put forth by members of his own cabinet and has even managed to cast doubt on U.S. commitment to the jointly-U.S.brokered multilateral Iran Nuclear Deal. As a result, allies are less likely to trust U.S. promises and U.S. threats will lose their forcefulness (Yarhi-Milo 2018, p. 68). Below we examine three standout cases illustrating how unpredictability about what constitutes policy and what constitutes bullshit by the U.S. president has affected the U.S. government's foreign affairs.

\subsection{Trump on NATO}


Because of Trump's statements as a candidate (and initially as president) on U.S. commitment to NATO, the relationship between the new administration and foreign allies was marked by uncertainty. Trump insisted that NATO was obsolete and continued to rebuke NATO allies for not meeting their financial contributions to the alliance. Such rhetoric left allies wondering whether the U.S. would meet its collective security obligations. In fact, President Trump chided NATO leaders during the Brussels summit on May $25^{\text {th }}, 2017$, proclaiming that " $[\mathrm{t}]$ wenty-three of the 28 member nations are still not paying what they should be paying and what they are supposed to be paying for their defense. This is not fair to the people and taxpayers of the United States" (Baker 2017a, para. 17). The speech that was drafted by the president's national security team contained a reaffirmation of the U.S. commitment to Article 5, the treaty's collective security clause. According to U.S. National Security officials, the speech, which had been cleared by National Security Adviser, H.R. McMaster, had been altered by Trump himself without consulting or even informing National Security Council (NSC) staff in advance. Like NATO leaders, NSC staff realized the line had been removed upon delivery of the speech (Glasser 2017). During the closed-door dinner, officials were further chastised by Trump and threatened that the U.S. would cut "back U.S. defense spending and have Europeans dole out 'back pay' to make up for their low defense spending if they didn't pony up quickly enough" (Gramer 2017, para. 6). The issue of Russia, recognized by NATO members, including the U.S. military and intelligence community, as the foremost conventional security threat to the West, was not brought up by Trump during the dinner (Gramer 2017).

In another extraordinary move, Trump tweeted during the NATO summit that "[e]veryone here is talking about why John Podesta refused to give the DNC server to the FBI and the CIA. Disgraceful!" (Lejeune 2017, para. 1). John Podesta was the campaign chairman for Hillary Clinton and had nothing to do with the DNC's handling of the data breach by Russian hackers. Combined with Trump's continued denial of the U.S. intelligence community's conclusion that Russia did interfere in the elections, even 
members of Congress questioned the president's position on transAtlantic security. The top Democrat on the House Intelligence Committee, Adam Schiff (D-Calif.) called on Trump to confront Russia over its "continued destabilization of the Ukraine" and stated that "[t]his is not putting America first, but continuing to propagate his own personal fiction at the country's expense" (Savransky 2017, para. 3-4). Trump only endorsed the collective defense clause when asked by a reporter during the Romanian president's visit at the White House two weeks after the summit (Baker 2017b). Trump's benign attitudes towards Russia are a stark departure from U.S. commitment to European security and while his insistence on European "back pay" may be informed by his nationalist platform, much of the president's position on NATO seems derived from his own ignorance. In his interview with the Associated Press, he admitted that he did not know much about NATO, so he concluded that it was obsolete:

They had a quote from me that NATO's obsolete. But they didn't say why it was obsolete. I was on Wolf Blitzer, very fair interview, the first time I was ever asked about NATO, because I wasn't in government. People don't go around asking about NATO if I'm building a building in Manhattan, right? So they asked me, Wolf ... asked me about NATO, and I said two things. NATO's obsolete - not knowing much about NATO, now I know a lot about NATO-NATO is obsolete, and I said, 'And the reason it's obsolete is because of the fact they don't focus on terrorism'. You know, back when they did NATO there was no such thing as terrorism. (Associated Press 2017, para. 98)

This episode is Cohenian in nature: caused by ignorance and apparent apathy about a core U.S. foreign policy commitment and undeterred by a historic bipartisan consensus on this issue, the president bullshitted. ${ }^{2}$ U.S. assurances on NATO's collective

\footnotetext{
${ }^{2}$ Another example of this type of bullshit (derived from complete ignorance on a topic) was Trump's false claim that he convinced the navy to use steam over the 'Electro-Magnetic Aircraft Launch System' on the aircraft carrier, USS Gerald R. Ford.
} 
security arrangement is vital not just for the deterrence value of the organization, but ultimately for U.S. trustworthiness vis-à-vis its allies and adversaries.

\subsection{The Qatar crisis}

Shortly following President Trump's visit to the Middle East on June 5, 2017, Saudi Arabia, Bahrain, Egypt, and the UAE cut diplomatic relations with Qatar and imposed an economic embargo due to its alleged support for terrorism. The effort to isolate Qatar over its relations with Iran and its generally independent foreign policy must be seen as part of Saudi Arabia's determination to balance against its regional peer competitor, Iran. Demands for the Qatari government included cutting diplomatic relations with Iran, ceasing relations with groups considered terrorist organizations, such as the Muslim Brotherhood, and closure of the AlJazeera news network. As Secretary of State Tillerson tried, and ultimately failed, to engage in shuttle diplomacy between the Gulf States and Qatar, the host country of U.S. Central Command, President Trump's statement on Qatar reflected Saudi rather than U.S. interests:

The nation of Qatar, unfortunately, has historically been a funder of terrorism at a very high level, and in the wake of that conference, nations came together and spoke to me about confronting Qatar over its behavior. So we had a decision to make: Do we take the easy road, or do we finally take a hard but necessary action? We have to stop the funding of terrorism. I decided, along with Secretary of State Rex Tillerson, our great generals and military people, the time had come to call on Qatar to end its funding - they have to end that funding - and its extremist ideology in terms of funding. (White House 2017, para. 5)

After the president suggested that the U.S. could move Central Command and continued with very pro-Saudi and UAE statements, the Pentagon had to intervene and reiterate that they had no intention of moving the U.S. military base (Lynch, M 2017). As Trump was lashing out against Qatar, the Pentagon was hosting the Qatari Defense Minister who signed a letter of offer and ac- 
ceptance for the purchase of F-15 QA fighter jets, estimated at $\$ 12$ billion (Brennan and Atwood 2017). Prior to that, Secretary of State Rex Tillerson had travelled to Doha and signed a Memorandum of Understanding (MOA) with the Qatari government in which the government pledged "to interrupt, disable terror financing flows and intensify counter-terrorism activities globally" (Gaouette and Cohen 2017, para. 7). Negotiations for the bilateral counter-terrorism agreement had already been under way for over a year.

Contrary to efforts and policy pursued by the Pentagon and State Department, the president undercut his own administration throughout the crisis by publicly siding with Saudi Arabia's position. This was an extraordinary incident in U.S. foreign policy. We are not witnessing what has happened throughout U.S. diplomatic history, which relates to executive infighting or bureaucratic dissent (e.g. when Secretary of State Cyrus Vance resigned in protest at President Carter's decision to use military force to bring back the U.S. hostages from Tehran in 1980). What happened during the Qatar crisis was that both the Department of State and the Department of Defense simply ignored statements issued by the president and instead carried out the exact opposite policy, for they realized that Trump - in the absence of the requisite substantive knowledge — offered nothing but off-the-cuff Cohenian bullshit.

\subsection{The madman strategy and North Korea}

The crisis that ensued between the U.S. and North Korea in August of 2017 was exacerbated by Trump's bullshit. U.S. and multilateral efforts at North Korean non-nuclear proliferation proved futile when North Korea tested a hydrogen bomb in 2016 and continued to make progress on its intercontinental ballistic missile (ICBM) system. The Trump administration's first major crisis with North Korea came after the regime successfully tested an ICBM and claimed that it could reach "anywhere in the world" (McKirdy 2017).

On August 7, Pyongyang accused the U.S. government of "trying to drive the situation of the Korean peninsula to the brink 
of nuclear war" after the UN Security Council unanimously adopted new sanctions in response to the ICBM tests (CNN 2017). Two days later, at his golf course in New Jersey, President Trump told reporters that "North Korea best not make any more threats to the United States... They will be met with fire and fury like the world has never seen" (Baker and Sang-Hun 2017, para. 1). White House staff and Trump's own cabinet members were caught off guard by what was described as improvised language by the president. Secretary Tillerson told reporters that "Americans should sleep well at night", reassuring the nation that nothing indicated that relations with the regime had "dramatically changed in the last 24 hours" (Trush and Baker 2017, para. 23).

It was after this threat that the North Korean regime threatened to strike the U.S. territory of Guam with medium-to-longrange strategic ballistic missiles. Throughout the crisis, the U.S. defense readiness alert system DEFCON remained at level 4 (normal, increased intelligence and strengthened security measures). DEFCON 5 is normal peacetime readiness and DEFCON 1 is maximum force readiness. In fact, in this case, Trump's penchant for impulsiveness and fabrication over engaging in a deliberate decision-making process to implement coherent strategies and policies even during a nuclear standoff does not meet the criteria of the "Madman Theory". Thomas Schelling's (2008) work on nuclear brinkmanship centers on the idea that it is best to be believed to be a little crazy. Threats are more credible if it appears leaders are not concerned that much about their own survival. Here, the "Madman Theory" asks for leaders to show impetuosity, irrationality, and automaticity (reprisals set to launch automatically) (Schelling 2008, pp. 92-126).

During nuclear brinkmanship, hostile leaders engage in a series of threats, exerting pressure on one another and ultimately sharing the risks that it may result in nuclear exchange. As a result, during this game of chicken, warring leaders only increase the risks gradually, giving themselves room for retreat and deescalation. It would be wrong, however, to credit Trump for effectively engaging in brinkmanship because it was his volatile rhetoric that exacerbated the crisis in the first place. After all, when 
news about the Neo-Nazi attacks in Charlottesville broke, Trump was distracted and his tweets and statements about North Korea immediately ceased (Beauchamp 2017). The threat of a nuclear strike was not a product of a strategic consensus by key foreign policy and military decision makers, but rather extemporaneous bullshit based on impulsiveness. Nuclear brinkmanship based on bullshit rather than reason is inherently dangerous, for nuclear deterrence may be underwritten by fear of your enemy's hostility but it is still tied to a government's credibility to execute threats.

Not only did the president not seem to care whether his threats described reality-U.S. defense posture at the time - correctly, he was also overridden by members of his own cabinet. He continued to undermine Tillerson's efforts to re-open dialogue with the regime in October, tweeting that the Secretary of State "was wasting his time", saying "save your energy Rex". Not unlike the NATO episode, Cohenian bullshit not only undermined U.S. credibility but also its signaling reputation (a state's record of carrying out threats or fulfilling promises), a key component for credible nuclear deterrence (Yarhi-Milo 2018, p.75). Trump continues to taunt the North Korean dictator on Twitter by comparing the size of nuclear buttons and vows to have the power to annihilate the country. In January 2018, Hawaii's Emergency Management Agency sent an emergency alert notification, because an employee had pushed the wrong button, that a ballistic missile was inbound. Nuclear war caused by human error or human bullshit remains a distinct possibility.

\section{Conclusion}

Trump's endgame is celebrity. He places no particular value on the meaning of words, for they are merely tools for a different purpose altogether. What is said one day can be discarded the next. Policy or strategy can be altered at an instant or discredited at the expense of cabinet members, the military, the intelligence community, or even his political allies in congress. A devout parishioner in the cult of celebrity, Trump will say what needs to be said, or do what needs to be done, in order to draw the irresistible gaze of the ce- 
lebrity machine, to be invited-with open arms or reluctant hesitation-into the homes of people around the globe through their TVs, their radios, or even better, their multi-platform technological devices. For Trump, being the topic of discussion is much more important than substantively contributing to the discussion itself. Lies, deception, and bullshit are integral parts of Trump's populist toolbox and he is not hesitant about their use. Even so, bullshit aimed at a domestic audience is very different than bullshit aimed at foreign ones. Historically, when populism has entered into foreign policy, the international community has always rallied against the country threatening the status quo.

It seems, however, that Trump is also facing increasing opposition at home and that his allies' tolerance for bullshit is decreasing. Congressional detractors in his own party, like Senator Jeff Flake (R-Ariz.) have started to publicly cast Trump's conspiracies and falsehoods as threats to democracy: "It's dangerous to democracy; you've got to have shared facts," [...] "And on so many of these, there's empirical evidence that says no: You didn't win the popular vote, there weren't more people at your inauguration than ever, that was your voice on that tape, you admitted it before" (Haberman and Martin 2017, para.12 ). Pressed about the president's values following the deadly violence in Charlottesville, VA, and whether those values are shared among members of the administration, Secretary of State, Rex Tillerson, unceremoniously told FOX's Chris Wallace that "the president speaks for himself, Chris" (The Editorial Board 2017, para. 3).

Acknowledgements: The authors would like to thank the anonymous reviewers, as well as the editors, for helpful feedback on earlier versions of this manuscript. 


\section{References}

Aberdein, Andrew. 2006. Raising the tone: Definition, bullshit, and the definition of bullshit. In Bullshit and philosophy: Guaranteed to get perfect results every time, eds. Gary L. Hardcastle and George A. Reisch, 151-170. Chicago, IL: Open Court.

Abramson, Alana. 2017. Justice Department confirms there is no evidence Barack Obama wiretapped Trump Tower. In Time Magazine (3 September 2017), accessed 30 November 2017: http:/time.com/4926141/barack-obama-donald-trump-wiretap-doj/

Adams, Becket. 2015. Hannity 'glad Donald Trump is in this race'. In Washington Examiner (17 August 2015), accessed 10 June 2017: http://www.washingtonexaminer.com/hannity-glad-donald-trump-isin-this-race/article/2570342

Arana, Gabriel. 2015. Rachel Maddow: Is Donald Trump's candidacy just a PR stunt? The Huffington Post (17 June 2015), accessed 10 June 2017:

http://www.huffingtonpost.com/2015/06/17/maddow-trumppresidential-candidacy $\mathrm{n} \quad 7603670$.html

Associated Press. 2017. Transcript of AP interview with Trump. In The Associated Press (23 April 2017), accessed 12 June 2017: https://apnews.com/c810d7de280a47e88848b0ac74690c83

Baker, Peter. 2017a. Trump says NATO allies don't pay their share. Is that true? In The New York Times (26 May 2017), accessed 17 August 2017:

https://www.nytimes.com/2017/05/26/world/europe/nato-trumpspending.html?mcubz=1

Baker, Peter. 2017b. Trump commits United States to defending NATO nations. In The New York Times (9 June 2017), accessed 12 June 2017: https://www.nytimes.com/2017/06/09/world/europe/trump-natodefense-article-5.html?mcubz=1

Baker, Peter and Choe Sang-Hun. 2017. Trump threatens 'fire and fury' against North Korea if it endangers U.S. In The New York Times $(8$ August 2017), accessed 23 August 2017:

https://www.nytimes.com/2017/08/08/world/asia/north-korea-unsanctions-nuclear-missile-united-nations.html

Beauchamp, Zach. 2017. While Trump was distracted, North Korea calmed down. That's not a coincidence. In Vox (15 August 2017), accessed 26 August 2017: 
https://www.vox.com/world/2017/8/15/16150412/trump-north-koreacharlottesville

Belfiore, Eleonora. 2009. On bullshit in cultural policy practice and research: Notes from the British case. International Journal of Cultural Policy 15(3): 343-359.

Bernstein, Jonathan. 2017. Trump's know-nothing tour de force. In Bloomberg (2017 May 11), accessed 14 June 2017:

https://www.bloomberg.com/view/articles/2017-05-11/trump-s-knownothing-tour-de-force

Bobic, Igor. 2015. Donald Trump is actually running for president. God help us all. In The Huffington Post (16 June 2015), accessed 14 June 2017:

http://www.huffingtonpost.com/2015/06/16/donald-trumppresident $\mathrm{n}$ 7595438.html

Brennan, Margaret and Kyle Atwood. 2017. Trump sells Qatar \$12 billion of U.S. weapons days after accusing it of funding terrorism. In CBS News (15 July 2017), accessed 21 August 2017: https://www.cbsnews.com/news/trump-sells-qatar-12-billion-armsdays-after-accusing-it-of-funding-terrorism/

Brooks, David. 2017. When the world is led by a child. In The New York Times (15 May 2017), accessed on 15 June 2017: https://www.nytimes.com/2017/05/15/opinion/trump-classifieddata.html

Carson, Thomas L. 2016. Frankfurt and Cohen on bullshit, bullshitting, deception, lying, and concern with the truth of what one says. Pragmatics \& Cognition 23(1): 53-67.Carter, Brandon. 2017. Ex-Obama DOJ official: Trump 'just admitted to obstruction of justice'. In The Hill (2 December 2017), accessed on 3 December 2017:

http://thehill.com/blogs/blog-briefing-room/news/362935-ex-obamadoj-official-trump-just-admitted-to-obstruction-of

Channel 4 News. 2017. "So does it matter if the video is fake"? In Facebook (29 November 2017) [Video file], accessed 1 December 2017: https://www.facebook.com/Channel4News/videos/10155456447536939 I

Cillizza, Chris. 2017. Kellyanne Conway offers alternative fact to explain why Trump isn't lying. In CNN (24 July 2017), accessed 28 July 2017:

http://www.cnn.com/2017/07/24/politics/kellyanne-conwaytrump/index.html 
CNN. 2017. North Korean nuclear timeline. In CNN (14 August 2017), accessed 22 August 2017:

http://www.cnn.com/2013/10/29/world/asia/north-korea-nucleartimeline---fast-facts/index.html

Cohen, Gerald Allen. 2002. Deeper into bullshit. In Contours of agency, eds. Sarah Buss and Lee Overton, 321-339. Cambridge, MA: The MIT Press.

Cox, Ana Marie. 2015. Bernie Sanders has heard about that hashtag. In The New York Times (17 August 2015), accessed 14 June 2017:

https:/www.nytimes.com/2015/08/23/magazine/bernie-sanders-hasheard-about-that-hashtag.html

C-SPAN. 2015. Donald Trump presidential campaign announcement full speech. In C-SPAN (16 June 2015) [Video file], accessed 12 June 2017:

https://www.youtube.com/watch?v=apjNfkysjbM

Dickerson, John. 2017. President Trump's interview in the Oval Office: Full transcript. In CBS News (1 May 2017), accessed 14 June 2017: http://www.cbsnews.com/news/president-trump-oval-office-interviewcbs-this-morning-full-transcript/

The Editorial Board. 2017. The president speaks for himself. In The New York Times (29 August 2017), accessed 30 August 2015: https:/www.nytimes.com/2017/08/29/opinion/american-values-arpaiopardon.html

Fabian, Jordan. 2017. Trump resurrects pig's blood myth after Barcelona attack. In The Hill (17 August 2017), accessed 17 August 2017: http://thehill.com/homenews/administration/346995-trump-resurrectspigs-blood-myth-after-barcelona-attack

Fish, Will. 2016. 'Post-truth' politics and illusory democracy. Psychotherapy and Politics International 14(3): 211-213.

FOX News. 2015. Trump announces White House bid, joins crowded GOP field. In FOX News (16 June 2015), accessed 13 June 2017: http://www.foxnews.com/politics/2015/06/16/trump-announces-whitehouse-bid-joins-crowded-gop-field.html

Frankfurt, Harry G. 2005. On bullshit. Princeton, NJ: Princeton University Press.

Frankfurt, Harry G. 2006. On truth. New York: Alfred A. Knopf.

Gaouette, Nicole and Zachary Cohen. 2017. U.S. and Qatar broker counter-terrorism agreement. In CNN Politics (11 July 2017), accessed 17 August 2017: 
http://www.cnn.com/2017/07/11/politics/tillerson-qatar-terrorismmemorandum-of-understanding/index.html

Glasser, Susan B. 2017. Trump national security team blindsided by NATO speech. In Politico (5 June 2017), accessed 17 August 2017: http://www.politico.com/magazine/story/2017/06/05/trump-natospeech-national-security-team-215227

Gold, Hadas. 2017. Trump seizes advantage in war with media. In Politico (28 June 2017), accessed 10 August 2017:

http://www.politico.com/story/2017/06/28/trump-cnn-war-media240069

Graham, David A. Leaked transcripts show how foreign leaders manipulate Trump. In The Atlantic (3 August 2017), accessed 12 January 2018:

https://www.theatlantic.com/international/archive/2017/08/anunprecedented-look-into-trumps-stagecraft/535794/

Gramer, Robbie. 2017. Trump discovers Article 5 after disastrous NATO visit. In Foreign Policy Magazine (9 June 2017), accessed 14 June 2017:

https://foreignpolicy.com/2017/06/09/trump-discovers-article-5-afterdisastrous-nato-visit-brussels-visit-transatlantic-relationship-europe/

Grim, Ryan and Danny Shea. 2015. A note about our coverage of Donald Trump's 'campaign.' In The Huffington Post (17 July 2015), accessed 10 August 2017:

http://www.huffingtonpost.com/entry/a-note-about-our-coverage-ofdonald-trumps-campaign us 55a8fc9ce4b0896514d0fd66

Haberman, Maggie and Johnathan Martin. 2017. Trump once said the 'Access Hollywood' tape was real. Now he's not sure. In The New York Times (28 November 2017), accessed 8 December 2017: https://www.nytimes.com/2017/11/28/us/politics/trump-accesshollywood-tape.html

Hardcastle, Gary L. and George A. Reisch. 2006. Bullshit and philosophy: Guaranteed to get perfect results every time, eds. Gary L. Hardcastle and George A. Reisch. Chicago, IL: Open Court.

Held, Amy. 2018. Trump says FBI missed 'signals' of Florida school shooting because of Russia probe. In NPR (18 February 2018), accessed 18 February 2018:

https://www.npr.org/sections/thetwoway/2018/02/18/586912701/trump-says-fbi-missed-signals-of-floridaschool-shooting-because-of-russia-probe 
Holt, Lester. 2017. President Trump: This Russia thing is a made up story. In NBC Nightly News with Lester Holt (11 May 2007) [Video file], accessed 5 December 2017:

https://www.nbcnews.com/nightly-news/video/president-trump-thisrussia-thing-is-a-made-up-story-941962819745

Jackson, Brooks. 2015. Trump tramples facts. In FactCheck.org (16 June 2015), accessed 11 June 2017: http://www.factcheck.org/2015/06/trump-tramples-facts/

James, Aaron. 2016. Assholes: A theory of Donald Trump. New York: Doubleday.

Kessler, Glenn, Meg Kelly and Nicole Lewis. President Trump has made 1,628 false or misleading claims over 298 days. In The Washington Post (14 November 2017), accessed 12 December 2017: https://www.washingtonpost.com/news/factchecker/wp/2017/11/14/president-trump-has-made-1628-false-ormisleading-claims-over-298days $/$ utm term $=.7 \mathrm{db} 5 \mathrm{dac} 464 \mathrm{~b} 2 \&$ wpisrc $=$ nl most\&wpmm $=1$

Kaussler, Bernd and Glenn Hastedt. 2017. U.S. foreign policy towards the Middle East: The realpolitik of deceit. London: Routledge.

Kotzee, Ben. 2007. Our vision and our mission: Bullshit, assertion, and belief. South African Journal of Philosophy 26(2): 165-175.

Kuhn, Thomas S. 1962. The structure of scientific revolutions. Chicago, IL: University of Chicago Press.

Lejeune, Tristan. 2017. Trump: 'Everyone here is talking about DNC, Podesta'. In The Hill (7 July 2017), accessed 14 August 2017: http://thehill.com/blogs/blog-briefing-room/news-otheradministration/340939-trump-everyone-here-is-talking-about-dnc

Lynch, Colum. 2017. Nikki Haley and Trump's doctrine of diplomatic chaos. In Foreign Policy Magazine (28 June 2017), accessed 10 September 2017:

http://foreignpolicy.com/2017/06/28/nikki-haley-and-trumps-doctrineof-diplomatic-chaos/

Lynch, Marc. 2017. Three big lessons from the Qatar crisis. In The Washington Post (14 July 2017), accessed 22 August 2017:

https://www.washingtonpost.com/news/monkeycage/wp/2017/07/14/three-big-lessons-of-the-qatarcrisis/?utm term $=. \mathrm{f52 \textrm {c } 4 1 \mathrm { d } 4 3 \mathrm { b } 3 5}$ 
Mackey, Robert. 2017. Fox News is planting thoughts in Donald Trump's head. In The Intercept (10 July 2017), accessed 17 August 2017: https://theintercept.com/2017/07/10/fox-news-plantingthoughts-donald-trumps-head/

McKirdy, Euan. 2017. North Korea tests missile it claims can reach 'anywhere in the world'. In CNN (4 July 2017), accessed 22 August 2017: http://www.cnn.com/2017/07/03/asia/north-korea-missile-japanwaters/index.html

Meet the Press with Chuck Todd. 2017. Full Feinstein interview: Flynn had to be directed (3 December 2017), accessed 11 December 2017: https://www.nbcnews.com/meet-the-press/video/full-feinsteininterview-flynn-had-to-have-been-directed-1108593731906

Olsson, Erik J. 2008. Knowledge, truth, and bullshit: Reflections on Frankfurt. Midwest Studies in Philosophy 32(1): 94-110.

OWN. 2015. Donald Trump teases a president bid during a 1988 Oprah show. In $O W N$ (25 June 2015) [Video file], accessed 10 June 2017: https://www.youtube.com/watch?v=SEPs17_AkTI

Parker, Ashley and Wagner John. 2017 Trump retweets inflammatory and unverified anti-Muslim videos. In Washington Post (29 November 2017), accessed 10 December 2017:

https://www.washingtonpost.com/news/postpolitics/wp/2017/11/29/trump-retweets-inflammatory-and-unverifiedanti-muslim-videos/?utm term $=.84$ ee5782ad2a

PolitiFact. 2017. A timeline of Donald Trump's false wiretapping claim. In PolitiFact (21 March 2017), accessed 10 June 2017:

http://www.politifact.com/truth-o-meter/article/2017/mar/21/timelinedonald-trumps-false-wiretapping-charge

Reisch, George A. 2006. The pragmatics of bullshit, intelligently designed. In Bullshit and philosophy: Guaranteed to get perfect results every time, eds. Gary L. Hardcastle and George A. Reisch, 33-47. Chicago, IL: Open Court.

Roberts, David. 2017. Donald Trump and the rise of tribal epistemology: Journalism cannot be neutral toward a threat to the conditions that make it possible. In Vox (19 May 2017), accessed 10 February 2018: https:/www.vox.com/policy-and-politics/2017/3/22/14762030/donaldtrump-tribal-epistemology

Sakama, Chiaki, Martin Caminada and Andreas Herzig. 2014. A formal account of dishonesty. Logic Journal of the IGPL 23(2): 259-294. 
Savransky, Rebecca. 2017. Schiff: Trump's Russia comments directly undermine U.S. interests. In The Hill (7 June 2017), accessed 17 August 2017:

http://thehill.com/homenews/house/340815-schiff-trumps-russiacomments-directly-undermine-us-interests

Schelling, Thomas. 2008. Arms and influence. New Haven, CT: Yale University Press.

Schmidt, Michael and Michael D. Shear. 2017. Comey asks Justice Dept. to reject Trump's wiretapping claim. In The New York Times (5 March 2017), accessed 19 July 2017:

https://www.nytimes.com/2017/03/05/us/politics/trump-seeks-inquiryinto-allegations-that-obama-tapped-his-phones.html? $\mathrm{r}=0$

Shafer, Jack. 2017. Trump the bully. In Politico Magazine (27 January 2017), accessed 12 June 2017:

http://www.politico.com/magazine/story/2017/01/trump-the-bully214698

Smagorinsky, Peter, Elizabeth Anne Daigle, Cindy O'Donnel-Allen and Susan Bynum. 2010. Bullshit in academic writing: A protocol analysis of a high school senior's process of interpreting Much Ado About Nothing. Research in the Teaching of English 44(4): 368-405.

Smith, David and Martin Pengelly. "I feel badly for General Flynn": Trump sympathizes with disgraced former aide. In The Guardian (4 December 2017), accessed 12 December 2017: https://www.theguardian.com/us-news/2017/dec/04/doesnt-makesense-incredulity-trumps-lawyer-john-dowd-take-blame-for-flynntweet

Stelter, Brian. 2017. White House press secretary attacks media for accurately reporting inauguration crowds. In CNN (21 January 2017), accessed 10 June 2017:

http://money.cnn.com/2017/01/21/media/sean-spicer-press-secretarystatement/index.html

Taibbi, Matt. 2015. Inside the GOP clown car. In Rolling Stone (12 August 2015), accessed 9 June 2017:

http://www.rollingstone.com/politics/news/inside-the-gop-clown-car20150812

Trush, Glenn and Peter Baker. 2017. Trump's threat to North Korea was improvised. In The New York Times (9 August 2017), accessed $25 \mathrm{Au}-$ gust 2017:

https://www.nytimes.com/2017/08/09/us/politics/trump-northkorea.html?mcubz=1 
Trump, Donald. 2017a. Terrible! Just found out that Obama had my "wires tapped" in Trump Tower just before the victory. Nothing found. This is McCarthyism! In Twitter (4 March 2017), accessed 14 June 2017:

https://witter.com/realdonaldtrump/status/837989835818287106

Trump, Donald. 2017b. How low has President Obama gone to tapp my phones during the very sacred election process. This is Nixon/Watergate. Bad (or sick) guy! In Twitter (4 March 2017), accessed 14 June 2017:

https://witter.com/realDonaldTrump/status/837996746236182529

Trump, Donald. 2017c. I never asked Comey to stop investigating Flynn. Just more Fake News covering another Comey lie! In Twitter (3 December 2017), accessed 3 December 2017: https://twitter.com/realdonaldtrump/status/937279001684598784?la ng=en

Trump, Donald. 2017d. After years of Comey, with the phony and dishonest Clinton investigation (and more), running the FBI, its reputation is in Tatters - worst in History! But fear not, we will bring it back to greatness. In Twitter (3 December 2017), accessed 3 December 2017:

https://witter.com/realdonaldtrump/status/937305615218696193?lan $\mathrm{g}=\mathrm{en}$

Wang, Amy B. 2016. 'Post-truth' named 2016 word of the year by Oxford Dictionaries. In The Washington Post (16 November 2016), accessed 11 June 2017:

https://www.washingtonpost.com/news/the-fix/wp/2016/11/16/posttruth-named-2016-word-of-the-year-by-oxford-dictionaries/

Ward, Alex. 2017. Trump just revealed a covert CIA program-over Twitter. In Vox (25 July 2017), accessed 17 August 2017: https:/www.vox.com/world/2017/7/25/16025136/trump-syria-ciatwitter-program-end-covert

Ward, Steven C. 1996. Reconfiguring truth: Postmodernism, science studies, and the search for a new model of knowledge. Lanham, MD: Rowman \& Littlefield.

Webber, Jonathan. 2013. Liar!. Analysis 73(4): 651-659.

West, Lindy. 2017. 100 Days of gibberish-Trump has weaponised nonsense. In The Guardian (25 April 2017), accessed 15 August 2017: https://www.theguardian.com/commentisfree/2017/apr/25/trump-100days-gibberish-weaponised-white- 
The White House. 2017. Remarks by President Trump and President Iohannis of Romania in a joint press conference (9 June 2017), accessed 11 June 2017: https://www.whitehouse.gov/the-pressoffice/2017/06/09/remarks-president-trump-and-president-iohannisromania-joint-press

Will, George. 2017. Trump has a dangerous disability. In The Washington Post (3 May 2017), accessed 11 June 2017:

https://www.washingtonpost.com/opinions/trump-has-a-dangerousdisability/2017/05/03/56ca6118-2f6b-11e7-953400e4656c22aa story.html?utm campaign=newsletter axiosam\&utm medium=email\&utm source $=$ newsletter\&utm term $=$. a9f $48771665 \mathrm{~b}$

Yarhi-Milo, Keren. 2018. After credibility: American foreign policy in the Trump era. Foreign Affairs 97(1): 68-77.

Zavattaro, Staci M. 2017. In defense of bullshit: Administrative utility of the philosophically ephemeral. Public Voices 15(1): 47-62. 